\title{
ACC

\section{La Automedicación en jóvenes en el contexto de la COVID-19}

\section{Self-medication in young people in the context of COVID-19}

\author{
Lisseth Dolores Rodriguez-Cruz *, 1, a \\ Irodriguez@usat.edu.pe
https://orcid.org/ 0000-0003-1742-9498 \\ Irodriguez@usat.edu.pe
https://orcid.org/ 0000-0003-1742-9498
}
${ }^{1}$ Escuela de Enfermería de la Universidad Católica Santo Toribio de Mogrovejo, Chiclayo, Perú
a Magister en Salud Pública

\section{Fechas importantes}

Recibido: 2021-11-01

${ }^{*}$ Autor corresponsal

Publicado online: 2021-12-17

Palabras clave: Automedicación, COVID-19, jóvenes

Keywords: Self-medication, young, COVID-19

La automedicación es un problema latente en nuestra sociedad. Es la iniciativa propia o decisión de tomar medicamentos el consumo de fármacos sin importar su origen, ni prescripción médica ${ }^{1,2}$. Esta ha ido en aumento y se ha vuelto un fenómeno muy estudiado por investigadores. Así, en épocas pre-pandemia la automedicación era un problema considerable en varios países, aunque con diferencias entre países de Europa y Latinoamérica. Así tenemos, en España ${ }^{3}$; el Sistema Nacional de Salud dio a conocer que en el año 2017 el $15,3 \%$ de personas se automedica. Asimismo, en México ${ }^{4}$; el $86 \%$ consume medicamentos sin la prescripción de un médico.

Sin embargo, el miedo, la saturación de hospitales y la afectación económica por la pandemia COVID- $19^{5}$ ha incentivado a realizar con más frecuencia esta práctica e inclusive aumentó la prevalencia en la población joven ${ }^{6}$. Puesto que, justificaban la práctica por diversos factores entre ellos; el 33,49 \% de los jóvenes relacionan la similitud de los síntomas con enfermedades pasadas, el 19,17 \% percibían la enfermedad como algo leve, el 18,24 \% desde el aspecto económico les resultaba más barato la automedicación. Además, en Perú, al inicio de la pandemia se distribuyó kits para tratar la enfermedad leve por coronavirus; por lo que algunos 
cuando eran hospitalizados por la enfermedad, referían haberse automedicado con ivermectina que les habían entregado a sus familiares ${ }^{8}$.

Además, la pandemia ha incrementado el consumo de tranquilizantes para tratar la ansiedad y el insomnio, trastornos que han aumentado a consecuencia de la pandemia9. En tal sentido, algunos por el miedo y la ansiedad, han optado por el automedicarse sustancias tales como el dióxido de cloro, vitaminas, hierbas, cloroquina ${ }^{10}$. En tanto, se usaron también medicamentos que permitan mejorar el sistema inmunológico como vitaminas $C, D, A$ y $B$ y suplementos de zinc $^{11}$.

Finalmente, la población, debido al SARS-CoV-2 como una acción preventiva y tranquilizadora, recurrió al acopio de fármacos y su eventual autoconsumo sin consultar con una prescripción. Sin embargo, fue una medida errónea debido a que existen fármacos como los antibióticos que debilitan el sistema inmune ${ }^{12}$.

Frente a lo expuesto, es necesario reflexionar que una consecuencia de la automedicación es la resistencia a los antibióticos, esta aumenta la letalidad de la enfermedad porque el tratamiento se vuelve más difícil debido a la pérdida de eficacia de los mismos. Por lo que es importante implementar en todas las farmacias la vigilancia del expendio de antibióticos, ansiolíticos, etc. con receta. Además, se debe concientizar a la población sobre los riesgos de la automedicación para la salud, puesto que puede causar resistencia a los antibióticos y la dependencia de ansiolíticos y analgésicos.

\section{Editorial}

Self-medication is a latent problem in our society. It is the own initiative or decision to take drugs, the consumption of drugs regardless of their origin, or medical prescription ${ }^{1,2}$. This has been increasing and has become a phenomenon that is highly studied by researchers. Thus, in pre-pandemic times, self-medication was a considerable problem in several countries, although with differences between countries in Europe and Latin America. So, we have, in Spain $^{3}$; The National Health System announced that in $201715.3 \%$ of people self-medicate. Also, in Mexico ${ }^{4}, 86 \%$ consume medications without a doctor's prescription.

However, fear, the saturation of hospitals and the economic impact of the COVID-19 pandemic ${ }^{5}$ has encouraged us to carry out this practice more frequently and even increased the prevalence in the young population ${ }^{6}$. Since they justified the practice by diverse factors among them; $33.49 \%$ of the young people relate the similarity of the symptoms to past illnesses, $19.17 \%$ perceived the illness as something mild, and $18.24 \%$, from the economic aspect, self-medication was cheaper for them ${ }^{7}$. In addition, in Peru, at the beginning of the pandemic, kits were distributed to treat mild coronavirus disease; Therefore, when some were hospitalized for the disease, they reported having self-medicated with ivermectin that they had given to their relatives ${ }^{8}$.

In addition, the pandemic has increased the use of tranquilizers to treat anxiety and insomnia, disorders that have increased as a result of the pandemic ${ }^{9}$. In this sense, some, out of fear and anxiety, have chosen to self-medicate substances such as chlorine dioxide, vitamins, 
herbs, chloroquine ${ }^{10}$. Meanwhile, medicines were also used to improve the immune system such as vitamins $C, D, A$ and $B$ and zinc supplements ${ }^{11}$.

Finally, the population, due to SARS-CoV-2 as a preventive and reassuring action, resorted to the collection of drugs and their eventual self-consumption without consulting a prescription. However, it was an erroneous measure because there are drugs such as antibiotics that weaken the immune system ${ }^{12}$.

Faced with the foregoing, it is necessary to reflect that a consequence of self-medication is resistance to antibiotics, this increases the lethality of the disease because treatment becomes more difficult due to their loss of efficacy. Therefore, it is important to implement surveillance of the sale of antibiotics, anxiolytics, etc. with prescription in all pharmacies. In addition, the population must be made aware of the risks of self-medication for health since it can cause resistance to antibiotics and dependence on anxiolytics and analgesics.

\section{Referencias}

1. Caamano F, Figueiras A, Lado E, Gestal J. La automedicación: concepto y perfil de sus "usuarios". Gaceta Sanitaria [Internet]. 2000 [Consultado 28 Sept 2021]; 14(4): 294-299. Disponible en: https://doi.org/10.1016/S0213-9111(00)71480-4

2. Hernández A. Farmacología General: Una guía de estudio. Madrid: McGraw-Hill; 2013. 242 p.

3. Gobierno de España. Las cifras de la automedicación en España. Revista Dirección General de Tráfico [Internet]. 2019 [Consultado 2 Oct 2021]. Disponible en: https://revista.dgt.es/es/multimedia/infografia/2020/01ENERO/0128Auto-Medicarse.shtml

4. DoctoraliaPress. $86 \%$ de mexicanos toma medicamentos sin prescripción médica. Estudio sobre la automedicación 2019 [Internet]. 2019 [Consultado 2 Oct 2021]. Disponible en: https://press.doctoralia.com.mx/79663-86-de-mexicanos-toma-medicamentos-sin-prescripcionmedica

5. Soler F, Calderón C, Pérez A. El Observatorio del Comportamiento de Automedicación de la Universidad del Rosario y su rol en la pandemia de covid-19. Revista Ciencias de la Salud [Internet]. 2020 [Consultado 29 Agos 2021]; 18(2): 1-11. Disponible en: https://revistas.urosario.edu.co/xml/562/56263561001/html/index.html

6. De la Luz. Automedicación y pandemia, combinación letal en Latinoamérica. SciDevNet [Internet]. 2021 [Consultado 2 Oct 2021]. Disponible en: https://www.scidev.net/americalatina/news/automedicacion-y-pandemia-combinacion-letal-en-latinoamerica/

7. Demelash Z, Basazn A, Ayalew D, Fentahun E. Self-medication Practice and Associated Factors among Private Health Sciences Students in Gondar Town, North West Ethiopia. A Cross-sectional Study. The Journal of Health Care Organization, Provision, and Financing [Internet]. 2021 [Consultado 16 Abr 2021]. 58: 1-10. Disponible en https://doi.org/10.1177/00469580211005188

8. Pérez A. Automedicación y covid-19. Revista Nova et Vetera [Internet]. 2020 [Consultado 2 Oct 2021]; 6(48). Disponible en: https://www.urosario.edu.co/Revista-Nova-EtVetera/Omnia/Automedicacion-y-covid-19/

9. Galaz O. Automedicación en pandemia: los riesgos de consumir tranquilizantes. Universidad San Sebastián: Instituto de Políticas Públicas en Salud [Internet]. 2020 [Consultado 2 Oct 2021]. Disponible en: http://www.ipsuss.cl/ipsuss/actualidad/automedicacion-en-pandemia-los-riesgosde-consumir-tranquilizantes/2020-07-28/125923.html

10. Soler F, Calderón C, Pérez A. El Observatorio del Comportamiento de Automedicación de la Universidad del Rosario y su rol en la pandemia de covid-19. Revista Ciencias de la Salud [Internet]. 
2020 [Consultado 29 Agos 2021]; 18(2): 1-11. Disponible en: https://revistas.urosario.edu.co/xml/562/56263561001/html/index.html

11. Khabour $\mathrm{O}$, Hassanein $\mathrm{S}$. Use of vitamin/zinc supplements, medicinal plants, and immune boosting drinks during COVID-19 pandemic: A pilot study from Benha city, Egypt. Heliyon [Internet]. 2021 [Consultado 12 Oct 2021]; 7(3): 1-6. Disponible en: https://doi.org/10.1016/j.heliyon.2021.e06538

12. Pérez A. Automedicación en los tiempos del COVID-19. Universidad del Rosario [Internet]. 2020 [Consultado 2 Oct 2021]. Disponible en: https://www.urosario.edu.co/Observatorio-delComportamiento-de-Automedicacion/documentos/Automedicacion-en-los-tiempos-del-COVID19.pdf

\section{Editor}

Escuela de Enfermería de la Universidad Católica Santo Toribio de Mogrovejo, Chiclayo, Perú

\section{Cómo citar este trabajo (llenado por la revista)}

Rodriguez-Cruz L. La automedicación en jóvenes en el contexto de la COVID-19. Acc Cietna: para el cuidado de la salud [Internet]. 2021; 8(2): 1 - 4 . Disponible en: https://doi.org/10.35383/cietna.v8i2.695

\section{Financiación}

El presente artículo no cuenta con financiación específica de agencias de financiamiento en los sectores público o privado para su desarrollo y/o publicación.

\section{Conflicto de interés}

El autor del artículo declara no tener ningún conflicto de intereses en su realización.

(c) Los autores. Este artículo es publicado por la Revista Acc Cietna: para el cuidado de la salud de la Escuela de Enfermería, Universidad Católica Santo Toribio de Mogrovejo.

Este es un artículo de acceso abierto, distribuido bajo los términos de la Licencia Creative Commons Atribución-NoComercial-CompartirIgual 4.0 Internacional (CC BY-NC-SA 4.0), que permite el uso no comercial, distribución y reproducción en cualquier medio, siempre que la obra original sea debidamente citada. 